\title{
Konflik Sosial Keagamaan Antar Muslim di Dusun Kecil dan Terpencil
}

\author{
Khoirul Mudawinun Nisa' \\ STAI Madiun, Madiun, Indonesia \\ mudawinunnisa@yahoo.coi.id
}

\begin{abstract}
Abstrac
At the time of the Prophet the mosque was used as a center of Islamic civilization. Therefore, many Muslim communities have been competing to establish mosques. On the other hand, the number of mosques has become the cause of religious and social conflicts among Muslim communities because of different ideological factors. This can be based on an analysis of the conflict manifestation in the dynamics of people's lives. Conflict Analysis on the reality of social life becomes a pretty impressive fact to be studied in order to place a social situation that develops in the midst of society in the basic framework of the right data and leads to an implementative position of its manifestation. Conflicts that arise in the midst of people's lives are part of the formation of the community itself. As happened in the village of Bener Betek Madiun district, with a population of 529 it has 2 mosques and 6 musholla. This phenomenon is interesting and important to study with the aim of covering the theory of social conflict by Ralf Dahrendorf. The method used in this study is qualitative method. The results of this study indicate that the prime causes of conflict in Bener Hamlet include: (1) ideological differences; (2) social inequality, (3) political power, (4) economy, and (5) domination of elite groups. The implication is to map social religious conflicts in rural areas.
\end{abstract}

Keywords: Social, religious, inter-Muslim conflict

\section{Pendahuluan}

Agama merupakan suatu hal yang kudus. Kekudusan tersebut tercermin pada ajaran yang dipandang sakral oleh para pemeluknya dan dijadikan acuan atau pedoman hidup. Setiap penganut agama berupaya sekuat mungkin untuk merealisasikan ajaran agama dalam perilaku sosial sehari-hari. Secara prinsipil, agama merupakan ajaran yang membawa nilainilai luhur seperti kebaikan, keadilan, kebersamaan, kesalehan dan menghendaki cinta kasih antar manusia. Akan tetapi disisi lain, agama juga dipandang memainkan peranan penting dalam timbulnya konflik. Dengan kata lain dalam aktualisasi kehidupan masyarakat tidak jarang muncul konflik-konflik sosial yang bernuansa agama atau menggunakan agama sebagai pelumas untuk meningkatkan eskalasi konflik.

Dalam kehidupan beragama di Dusun Bener Desa Betek Kecamatan Madiun Kabupaten Madiun dalam kurun waktu 10 tahun terakhir sering terjadi berbagai persoalan menyangkut hubungan antar muslim. Dalam kasus pertikaian atau konflik antar muslim di Dusun Bener ini menghasilkan berbagai persoalan baru yang merusak kehidupan dan keharmonisan antar muslim. Masyarakat di Dusun kecil dan terpencil ini terdiri dari 529 penduduk yang seluruhnya menganut agama Islam. Masyarakat yang dulu menjunjung tinggi nilai kearifan lokal seperti gotong royong, tepo seliro, guyub rukun dan sambatan, kini sudah hampir "punah". Berdirinya 1 masjid lama (berdiri tahun 1954), 6 musholla dan 1 masjid dalam proses pembangunan menjadi bukti nyata adanya kerenggangan kohesitas antar muslim di dusun Bener. Masjid Imam Muslim (masjid lama) yang dulu dijadikan sebagai center of islamic civilization kini jama'ah sholat fardunya berkurang, kegiatan kegamaanpun seperti sholat terawih, TPQ, sholawat dan hadroh bagi remaja, pembelajaran diba' dan barzanji kini telah beralih kemasing-masing musholla. 
Konflik yang terjadi di Dusun Bener menggambarkan teori konflik sosial oleh Dahrendorf (1959, 1968) yang berpendapat bahwa di dalam setiap asosiasi yang ditandai oleh pertentangan terdapat ketegangan diantara mereka yang ikut dalam struktur kekuasaan dan mereka yang tunduk pada struktur itu. Terdapat kelompok semu dan kelompok kepentingan. Kepentingan yang dimaksud Dahrendorf mungkin bersifat manifest atau laten. Kepentingan laten adalah tingkah laku potensial yang telah ditentukan bagi seseorang karena ia menduduki peranan tertentu, tetapi masih belum disadari. Jadi seseorang dapat menjadi anggota suatu kelas yang tidak memiliki kekuasaan, tetapi sebagai kelompok mungkin mereka tidak menyadari. Hal ini merupakan beberapa kasus dari banyak kelompok-kelompok minoritas yang telah muncul kesadarannya antara lain; kelompok kulit hitam, wanita, suku Indian dan Chicanos. Demikian juga, kepentingan-kepentingan yang tidak disadari, misalnya persamaan gaji, persamaan kesempatan kerja, kemudian berkembanglah organisasi-organisasi yang disebut Dahrendorf ebagai kelompok-kelompok manifes.

Konflik sosial keagamaan antar umat muslim di dusun Bener menarik untuk diteliti karena analisis konflik pada realitas kehidupan sosial menjadi fakta yang cukup mengesankan untuk dikaji dalam rangka menempatkan situasi sosial yang berkembang di tengah-tengah masyarakat pada kerangka dasar data yang tepat serta mengarah kepada posisi impelementatif dari perwujudannya. Konflik yang muncul di tengah-tengah kehidupan masyarakat merupakan bagian dari pembentukan masyarakat itu sendiri. Untuk itu, penelitian ini bertujuan untuk mengcover teori konflik sosial oleh Ralf Dahrendorf dengan melihat konflik dari : (a) causa-prima terjadinya konflik sosial keagamaan di dusun Bener, (b) bentuk konflik sosial keagamaan di dusun Bener, dan (c) dampak konflik sosial keagamaan terhadap perubahan sosial.

\section{Kerangka Dasar Teori}

Ralf Dahrendorf, ${ }^{1}$ melihat teori konflik sebagai teori parsial yang dapat juga digunakan dalam menganalisa fenomena sosial yang ada, dengan pengertian bahwa disamping penggunaan teori strukturalisme fungsional, dimana dalam hal ini Dahrendorf, (1959) merupakan pengritik teori fungsional yang mengabaikan keberadaan potensi konflik dalam masyarakat. Dahrendorf, ${ }^{2}$ menganggap masyarakat bersisi ganda, memiliki sisi konflik dan sisi kerja sama (kemudian ia menyempurnakan posisi ini dengan menyatakan bahwa segala sesuatu yang dapat dianalisa dengan fungsionalisme struktural dapat pula dianalisa dengan teori konflik dengan lebih baik).

Konflik merupakan suatu bentuk interaksi sosial ketika dua individu mempunyai kepentingan yang berbeda dan kehilangan keharmonisan di antara mereka. Menurut Dahrendorf (1959), pada dasarnya konflik merupakan hal yang alamiah dan sering terjadi dalam kehidupan sehari-hari. Dalam penulisan ini beberapa teori konflik yang akan digunakan adalah teori konflik Ralf Dahrendorf (1959), pemikiran dari tokoh tersebut mengenai teori konflik akan dijadikan sebagai bahan dalam landasan teori dalam penulisan ini.

Teori konflik berorientasi ke studi struktur dan institusi sosial. Dahrendorf, (1959) teoritisi konflik lainnya, setiap masyarakat tunduk pada proses perubahan. Teoritisi konflik juga melihat pertikaian dan konflik dalam sistem sosial, Teoritisi konflik juga melihat berbagai elemen kemasyarakatan menyumbang terhadap disintegrasidan perubahan,

\footnotetext{
1 Dahrendorf, Ralf. 1995. "Class and Calss Conflict in Industrial Society". In David B. Grusky (ed.), Social Statification: Class, Race, and Gender in Sociological Perspective. Boulder-San Francisco-Oxford: Westview Press. 180 2 Ibid,. 173
} 
teoritisasi konflik menekankan pada peran kekuasaan dalam mempertahankan ketertiban dalam masyarakat.

\section{Bentuk Konflik menurut Dahrendorf}

Dalam kelanjutannya, ada beberapa bentuk konflik menurut Ralf Dahrendorf yang dilihat dari berbagai sudut pandang.

\section{- Konflik Peran}

Bentuk konflik peran merupakan suatu kondisi dimana seseorang mendapati kenyataan yang berlawanan dengan perannya dalam kehidupan nyata. Contoh kasus teori konflik Ralf Dahrendorf ini adalah peran seorang pekerja yang ternyata dituntut untuk mengerjakan sesuatu yang bukan menjadi tanggung jawabnya.

\section{- Konflik Kelompok Sosial}

Konflik antara kelompok sosial terjadi karena adanya perbedaan kepentingan dalam upayanya mencukupi kebutuhan kelompok tersebut. Contoh konflik antar kelompok sosial adalah konflik antara kelompok Pro Pemerintah dan kelompok Anti Pemerintah di suatu negara.

- Konflik antar Kelompok yang Terorganisir dan Kelompok yang tidak Terorganisir

Konflik ini biasanya terjadi saat unjuk rasa. Dimana polisi, kelompok yang terorganisir dan memiliki tujuan yang jelas harus mengatasi masa pendemo yang tidak terorganisir, brutal dan semena-mena.

- Konflik Antar Satuan Nasional

Konflik ini juga disebut sebagai konflik antar kepentingan organisasi. Contoh kasus teori konflik Ralf Dahrendorf adalah konflik organisasi politik di tingkat RT, RW, Desa, Kecamatan hingga tingkat Nasional.

\section{- Konflik Antar Agama}

Konflik ini sering terjadi di jaman dahulu, dimana konsep toleransi belum diadopsi oleh masyarakat tradisional.

\section{Metode}

Metode yang digunakan dalam penelitian ini adalah metode penelitian kualitatif dengan pendekatan interaktif studi kasus, karena dilakukan dengan studi mendalam pada suatu kesatuan sistem dengan menghimpun data, kemudian mengambil maknanya, sehingga memperoleh gambaran secara lengkap tentang kasus konflik sosial keagamaan di Dusun Bener Desa Betek Kecamatan Madiun Kabupaten Madiun.

Dalam penelitian ini, peneliti menggunakan teori konflik Dahrendorf dimana manusia adalah makhluk sosial yang mempunyai andil dalam terjadinya disintegrasi dan perubahan sosial. Masyarakat selalu dalam keadaan konflik menuju proses perubahan. Masyarakat dalam berkelompok dan hubungan sosial didasarkan atas dasar dominasi yang menguasai orang atau kelompok yang tidak mendominasi. Teori konflik memandang masyarakat disatukan oleh ketidakbebasan yang dipaksakan. ${ }^{3}$ Dengan demikian, posisi tertentu di dalam masyarakat mendelegasikan kekuasaan dan otoritas terhadap posisi yang lain. Fakta kehidupan sosial ini mengarahkan Dahrendorf kepada tesis sentralnya bahwa perbedaan distribusi otoritas selalu menjadi faktor yang menentukan konflik sosial sistematis.

Pengumpulan data mengenai konflik sosial dalam masyarakat desa dilakukan dengan observasi dengan mengamati aktivitas dan peristiwa di Dukuh Pulutan, wawancara

\footnotetext{
${ }^{3}$ George Ritzer. Sosiologi Ilmu Berparadigma Ganda. (Jakarta: Rajawali Press. 2003), 153
} 
kepada subjek penelitian tentang faktor, pihak, bentuk, dampak, dan solusi konflik. Data yang diperoleh selanjutnya dipilah-pilah atau diseleksi sesuai masalah penelitian. Data yang sudah diseleksi kemudian disajikan, sehingga dapat diperoleh gambaran tentang Konflik sosial di Dusun Bener. Selanjutnya dapat ditarik suatu kesimpulan.

Objek penelitian ini adalah konflik sosial keagamaan dalam masyarakat desa di Dusun Bener Desa Betek Kecamatan Madiun Kabupaten Madiun. Utamanya mengenai faktor, bentuk dan dampak dari konflik tersebut. Sumber data dalam penelitian ini antara lain narasumber atau informan, peristiwa dan aktivitas, arsip atau dokumen. Narasumber atau informan takmir masjid Imam Muslim, tokoh agaman, dan tokoh masyarakat. Sedangkan peristiwa dan aktivitas meliputi hubungan sosial masyarakat dalam kehidupan sehari-hari, perilaku pihak yang terlibat konflik, politik, aktivitas ibadah keseharian sholat fardu dan aktivitas keagamaan seperti TPQ, latihan sholawat dan barzanji bagi remaja, sholat tarawih kegiatan rutin yasainan dan lain sebaginya.

Analisa data dilakukan melalui kegiatan klarifikasi data yang telah berhasil dikumpulkan dari berbagai sumber berdasarkan unsur-unsur fenomenologi seperti data pola-pola konflik kegamaan yang terjadi, hubungan-hubungan sosial antar muslim dan datadata penting lainnya. Data yang sudah diklarifikasikan dibantu dengan teori-teori kemudian direkonstruksi dengan pendekatan kualitatif ke dalam sebuah diskripsi yang kemudian di analisis hingga memungkinkan untuk diambil kesimpulan..

\section{Hasil}

\section{Causa Prima Terjadinya Konflik Keagamaan}

Konflik sosial keagamaan di Dusun Bener Desa Betek Kecamatan Madiun Kabupaten Madiun bergejolak pasca meninggalnya pemuka agama mbah yai Imam Mawardi. Beliau adalah sosok sesepuh agama yang dita'dzimi oleh seluruh masyarakat dusun Bener. Semasa hidupnya beliu banyak memberi kontribusi bagi perkembangan keagmaan baik berupa gagasan, nilai-nilai maupun aplikasinya. Masyarakat dusun Bener yang dulunya tergolong masyarakat yang sangat awam terhadap agama berhasil dipengaruhinya dengan pendekatan dakwah yang efektif yaitu berbaur dengan masyarakat.

Semasa beliau hidup, beliau bersama istrinya bu nyai Ambarwati mendirikan Taman Pendidikan Al-Qur'an (TPQ) al-Furqon. Diawal pembelajaran tak banyak santri yang mengaji namun ditahun-tahun berikutnya santri terus bertambah hingga pernah mencapai kurang lebih 130 santriwan-santriwati dari kalangan anak-anak dan remaja. Ba'da maghrib mbah yai pun mulai mengajak bapak-bapak untuk belajar Baca Tulis Al-Qur'an yang kemudian disambung dengan mauidzoh pengetahuan agama. Disamping itu, mbah yai Imam Mawardi juga beranggapan bahwa tidak hanya anak-anak, remaja dan bapak-bapak saja yang diberikan pengetahuan tentang keagamaan, tetapi ibu-ibu sebagai madrasah pertama bagi anak-anaknya juga harus dibekali pengetahuan keagamaan supaya tidak salah dalam mendidik anak-anaknya. Oleh karena itu, mbah yai mengadakan rutinan yasinan ibuibu 1 dusun Bener setiap hari kamis ba'da magrib dengan agenda mauidzoh wawasan keagamaan, pembacaan yasin dan tahlil. Nilai-nilai agama tentang ta'awun, tasammub benarbenar diinternalisasikan kedalam kehidupan masyarakat dusun Bener, seperti : ketika ada warga yang meninggal, maka seluruh masyarakat baik laki-laki maupun perempuan dianjurkan untuk off dari semua pekerjaannya guna membantu proses pemakaman jenazah. Tidak hanya itu, ketika ada salah satu warga yang hendak mengadakan walimatul ursy pun seluruh masyarakat dusun Bener dianjurkan untuk hurmat pengantin dengan menghadiri acara walimatul ursy. Maka tak ayal, ketika ada salah satu warga dusun Bener yang meninggal atau "mantu", tak ada satupun rumah yang terbuka pintunya. 
Pasca meninggalnya mbah yai Imam Mawardi tahun 2006 estafet kepemimpinan diberikan kepada menantunya yaitu pak yai Abu Amar. Segala kegiatan keagamaan dipegang oleh beliau. Bagi pak yai Abu Amar menggantikan posisi mbah yai Imam Mawardi yang sangat karismatik dan banyak membawa perubahan kearah positif dalam kehidupan masyarakat dusun Bener memang tak mudah. Akhirnya pak yai Abu Amar merombak struktur kepengurusan ta'mir masjid Imam Muslim beserta job discriptionnya untuk memperkokoh kegiatan keagamaan di dusun Bener yang sebelumnya sudah pernah ada tetapi tidak berjalan. Strategi perombakan kepengurusan tersebut tidak disambut baik oleh beberapa masyarakat, mereka menilai struktur kepengurusan ta'mir masjid imam muslim yang mayoritas dipegang oleh Bani Yahya ada unsur politik kekeluargaan yang ingin memasyhurkan nama keluarga Bani Yahya lewat pemberdayaan masjid.

Program baru yang dibuat oleh ta'mir masjid yaitu penambahan uang kas masjid untuk kegiatan sosial keagamaan melalui donatur tetap yang nama-namanya sudah ditentukan sekitar 30 orang dan ditarik setiap bulan dianggap oleh beberapa pihak sebagai "unsur shodaqoh pemaksaan" karena donatur tetap yang nama-namanya sudah ditentukan didatangi kerumahnya setiap bulannya dan dimintai shodaqoh. Tidak cukup disitu, program yasinan ibu-ibu setiap hari kamis yang sebelumnya penceramah hanya mbah yai Imam Mawardi pasca perombakan pengurus ta'mir masjid penceramah digilir ada 5 orang yang seluruhnya dari Bani Yahya dianggap kurang tepat oleh beberapa masyarakat dusun Bener karena tidak memberdayakan kemampuan tokoh agama yang bukan dari Bani Yahya. Perbedaan ideologi tersebut menjadi akar merengganya kohesivitas hubungan sosial masyarakat yang disebabkan karena perbedaan kepentingan, pendapat dan ekspresi pelaksanaan ibadah. Perbedaan kepentingan individu dan kelompok masyarakat Dusun Bener terjadi dalam peristiwa politik dan kegiatan keagamaan. Dalam politik ditunjukkan dengan perombakan kepengurusan ta'mir masjid imam muslim yang didominasi oleh keluarga Bani Yahya sehingga menimbulkan gesekkan kepentingan antar kelompok, sedang dalam kegiatan keagamaan terjadi pada kepentingan pelaksanaan kegiatan keagamaan.

Dari perbedaan ideologi tersebut timbullah inisiatif dari kubu yang tidak sefaham dengan pengurus dan program ta'mir masjid Imam Muslim untuk mendirikan musholla dan melaksanakan semua kegiatan keagaamaan dimushola tersebut. Konflik berlanjut pada kubu lain yang mana diwilayahnya sudah berdiri musholla tidak mau bergabung dengan wilayah pendiri musholla baru dan akan tetap memberdayakan musholla tersebut sebagai pusat keagamaan dikubunya, hingga ada 5 musholla di dusun Bener yang aktif melaksanakan kegiatan keagamaan dimasing-masing musholla kecuali 1 musholla karena memang musholla tersebut milik keluarga Bani Yahya. Sedangkan perbedaan ekspresi dalam ibadah atau peribadatan terjadi karena adanya penekanan dari pihak pengurus masjid imam muslim kepada tokoh agama di masing-masing musholla untuk memusatkan segala bentuk kegiatan keagamaan seperti TPQ, sholat tarawih, latihan sholawat dan hadroh, serta diba' dan barzanji di masjid Imam Muslim. Namun seluruh kubu yang tidak sefaham dengan ta'mir masjid tidak berkenan, sehingga konflik terus berlanjut.

Adanya i'tikad baik pihak ta'mir masjid Imam Muslim dengan mengadakan musyawarah untuk memusatkan seluruh kegiatan keagamaan di masjid tidak disambut baik oleh kubu utara. Bulan Desember 2016, terpajang sebuah Benner besar bertuliskan "DISINI AKAN DIBANGUN MASJID" pada tanah berukuran $12 \mathrm{~m}$ x 17 Meter menjadi gelombang besar yang menghantam masyarakat kubu selatan karena sebelumnya tidak ada musyawarah dan bahkan issue terkait dengan pendirian masjid baru di kubu utara. Kekhawatiran pengurus ta'mir masjid adalah semakin merenggangnya kohesivitas masyarakat dusun Bener karena terpecah belahnya kegiatan keagaman apalagi masjid yang baru berdiri dipelori oleh pendatang yang berasal dari Tomboro Kabupaten Magetan yang 
mana daerah tersebut merupakan pusat pengembangan islam garis keras didaerah jawa timur dan ditakutkan pelopor masjid baru di kubu utara membawa paham islam garis keras di dusun Bener.

\section{Bentuk Konflik dan Pihak yang Terlibat}

Konflik di Dusun Bener berupa konflik pribadi, kepentingan politik, dan ekspresi dalam ibadah atau peribadatan. Konflik pribadi terjadi antara individu dengan individu lain yang disebabkan karena motif tertentu berupa unsur persaingan untuk memperkuat kedudukan di masyarakat. Kepentingan pribadi tersebut melahirkan kelompok pemicu konflik. Konflik kepentingan politik terjadi karena perbedaan pandangan antar kelompok. Perbedaan tersebut mengakibatkan benturan antar kelompok. Sedangkan Konflik ekspresi dalam ibadah atau peribadatan merupakan konflik yang dijadikan sebagai sarung, batu loncatan, tameng sekaligus alat untuk mengungkapkan perbedaan ideologi kelompok Dusun Bener. Bentuk konflik berupa pelaksanaan keagamaan yang dulunya berpusat di masjid Imam Muslim kini terpecah-pecah kedalam masing-masing musholla seperti kegiatan TPQ, sholat sunnah tarawih, pembagian zakat fitrah, rutinan yasinan, tahlilan, kegiatan diba' dan barzanji.

Konflik di atas dipengaruhi oleh pihak-pihak yang terlibat memicu konflik antara lain tokoh agama, anggota masyarakat dan pemuda. Tokoh agama yang terlibat adalah keluarga yang mempunyai musholla, mumpuni dibidang keagamaan dan mempunyai pengaruh terhadap masyarakat. Anggota masyarakat Dusun Bener yang terlibat konflik adalah penduduk asli maupun pendatang yang menjadi propokator kelompoknya. Pemuda hanya menjadi alat untuk terlibat konflik. Sebenarnya pemuda tidak ada potensi untuk konflik. Namun karena pengaruh dari orang tuanya mereka menjadi terlibat konflik.

\section{Dampak Konflik Sosial Keagamaan}

Konflik berdampak pada pihak yang terlibat langsung maupun tidak langsung. Dampak dimaksud bisa positif atau negatif yang juga berpengaruh pada kehidupan masyarakat. Dampak konflik keagamaan di Dusun Bener berupa dampak dalam peribadatan dan dampak bagi antar individu dan antar kelompok. Dampak dalam peribadatan meliputi dampak positif dan dampak negatif. Dampak positif terdapat pada pemanfaatan tempat ibadah secara intensif dalam keseharian, masyarakat aktif dalam berjamaah, bersemangat dalam bersedekah dan memperindah masing-masing mushollanya, serta memperlihatkan keistiqomahan dalam berjamaah. Selain Dampak positif nampak adanya dampak negatif dalam peribadatan, yaitu keaktifan ibadah menjadi persaingan kelompok seolah hanya sebagai motivasi, saling menonjolkan kemampuan kelompok pada kegiatan di musholla masing-masing. Selain itu kesempatan untuk bersilaturrahim pada hari raya Idhul Fitri terabaikan, bahkan menjadi alat penekan kelompok lain. Juga keberadaan 1 masjid, 6 musholla dimanfaatkan sebagai pemicu pecahnya masyarakat Dusun Bener. Sedangkan dampak bagi antar individu dan antar kelompok, merenggangnya hubungan sosial dalam masyarakat baik individu maupun kelompok, membuat solidaritas masyarakat Dusun Bener berkurang, rasa kekeluargaan memudar, selalu berprasangka jelek, dan suka mengatasnamakan kegiatan milik kelompok bukan masyarakat.

\section{Pembahasan}

\section{Otoritas dalam Teori Konflik}

Dahrendorf memusatkan perhatian pada struktur yang lebih luas. Inti tesisnya adalah gagasan bahwa berbagai posisi di dalam masyarakat mempunyai kualitas otoritas yang berbeda. Otoritas tidak terletak di dalam diri individu, tetapi di dalam posisi. Otoritas yang 
melekat pada posisi adalah unsur kunci dalam analisis Dahrendorf. Otoritas secara tersirat menyatakan superordinasi dan subordinasi. Mereka yang menduduki posisi otoritas diharapkan mengendalikan bawahan. Artinya, mereka berkuasa karena harapan dari orang yang berada di sekitar mereka, bukan karena ciri-ciri psikologis mereka sendiri. Seperti otoritas, harapan ini pun melekat pada posisi, bukan pada orangnya. Otoritas bukanlah fenomena sosial yang umum; mereka yang tunduk pada kontrol dan mereka yang dibebaskan dari kontrol, ditentukan di dalam masyarakat. Terakhir, karena otoritas adalah absah, sanksi dapat dijatuhkan pada pihak yang menentang.

Menurut Dahrendorf, otoritas tidak konstan karena ia terletak dalam posisi, bukan di dalam diri orangnya. Karena itu seseorang yang berwenang dalam satu lingkungan tertentu tak harus memegang posisi otoritas di dalam lingkungan yang lain. Begitu pula seseorang yang berada dalam posisi subordinat dalam satu kelompok, mungkin menempati posisi yang superordinat dalam kelompok lain. Ini berasal dari argumen Dahrendorf yang menyatakan bahwa masyarakat tersusun dari sejumlah unit yang ia sebut asosiasi yang dikoordinasikan secara imperatif. Masyarakat terlihat sebagai asosiasi individu yang dikontrol oleh hierarki posisi otoritas. Karena masyarakat terdiri dari berbagai posisi, seorang individu dapat menempati posisi otoritas di satu unit dan menempati posisi yang subordinat di unit lain. Saat kekuasaan merupakan tekanan (coersive) satu sama lain, kekuasaan dalam hubungan kelompok-kelompok terkoordinasi ini memeliharanya menjadi legitimate dan oleh sebab itu dapat dilihat sebagai hubungan "authority", dimana beberapa posisi mempunyai hak normatif untuk menentukan atau memperlakukan yang lang lain.

Otoritas dalam setiap asosiasi bersifat dikotomi, karena itu ada dua, kelompok konflik yang dapat dibentuk di dalam setiap asosiasi. Kelompok yang memegang posisi otoritas dan kelompok subordinat yang mempunyai kepentingan tertentu "yang arah dan substansinya saling bertentangan". Di sini kita diperhadapkan dengan konsep kunci lain dalam teori konflik Dahrendorf, yakni kepentingan. Kelompok yang berada di atas dan yang berada di bawah didefinisikan berdasarkan kepentingan bersama. Dahrendorf tetap menyatakan bahwa kepentingan itu, yang sepertinya tampak sebagai fenomena psikologi, pada dasarnya adalah fenomena berskala luas ${ }^{4}$.

Konflik yang terjadi antara pengurus ta'mir masjid imam muslim dengan masyarakat jika merujuk pada teori otoritas Dahrendorf, maka dapat disimpulkan bahwa pengurus ta'mir masjid imam muslim merupakan pihak pemegang otoritas sementara masyarakat tidak memegang otoritas. Dalam hal ini, masyarakat berada pada posisi ketidakbebasan yang dipaksakan. Sementara itu, pengurus ta'mir masjid didelegasikan kekuasaan dan otoritas. Maka dari itu, pengurus ta'mir masjid memiliki kewenangan untuk membuat program baru. Berdasarkan kasus konflik sosial keagamaan di dusun Bener, peneliti melihat adanya perbedaan ideologi antar pemegang kekuasaan (pengurus ta'mir masjid) dengan masyarakat.

Proses sosial yang ditekankan dalam model konflik berlaku untuk hubungan sosial antara kelompok dalam (ingroup) dan kelompok luar (out-group). Kekuatan solidaritas internal dan integrasi kelompok dalam (in-group) akan bertambah tinggi karena tingkat permusuhan atau konflik dengan kelompok luar (out-group) bertambah besar. Dengan adanya 2 sisi tersebut terjadi suatu bentuk integrasi yang kuat antara kelompok pedagang sebagai kelompok yang merasa dirugikan dengan pembuat kebijakan yaitu Dinas Pasar. Kelompok pedagang ini melakukan perlawanan dengan cara memperkuat in groupnya agar dapat melawan kebijakan dari Dinas Pasar.

\footnotetext{
${ }^{4}$ Ibid, 175.
} 
Maka jika dilihat apa yang terjadi di dusun Bener, konflik yang terjadi sebagai akibat situasi dimana keinginan atau kehendak kelompok otoritas atau superordinat yang berbeda atau berlawanan antara satu dengan kelompok subordinat, sehingga salah satu atau keduanya saling terganggu yang menimbulkan ketidakcocokan antar nilai atau tujuan-tujuan yang ingin dicapai, baik yang ada dalam diri individu maupun dalam hubungannya dengan orang lain. Dari situ, muncullah kelompok-kelompok pembelot yang menyebabkan konflik terjadi.

\section{Gambar 1.1}

\section{Otoritas dalam Asosiasi Masyarakat Dusun Bener}

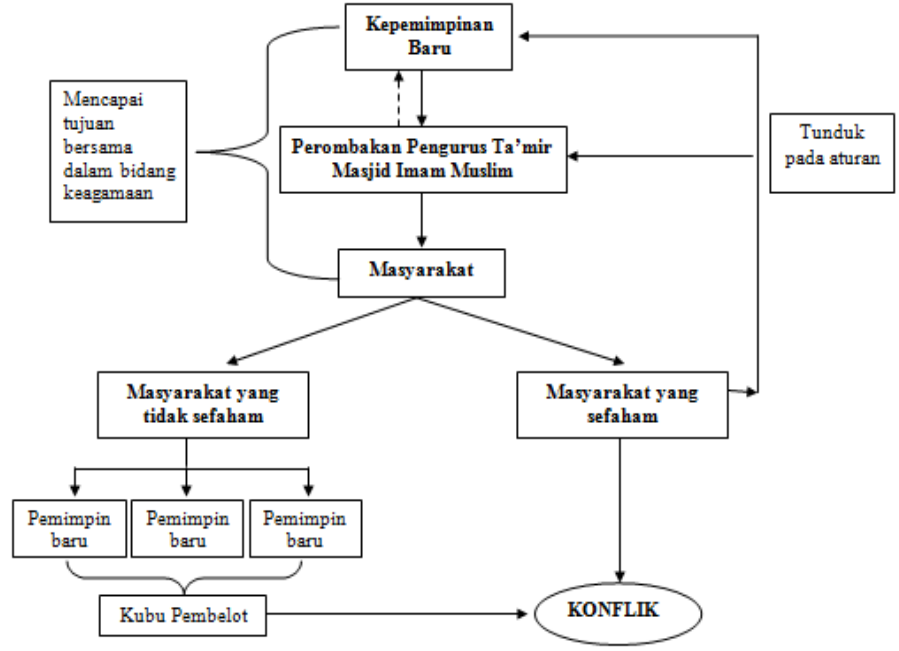

Menurut Wood, Walace, Zeffane, Schermerhom, Hunt dan Osbon yang dimaksud dengan konflik (dalam ruang lingkup organisasi) adalah: "Conflict is a situation which two or more people disagree over issue of organizational susbstance and/or experience some emotional antagonism with one other". Yang kurang lebih memiliki arti bahwa konflik adalah suatu ituais dimana dua atau banyak orang saling tidak setuju terhadap suatu permasalahan yang menyangkut kepentingan organisasi dan/ atau dengan timbulnya perasaan permusuhan satu dengan yang lainnya. ${ }^{5}$

Menurut Stoner konflik organisasi adalah mencakup ketidaksepakatan soal alokasi sumber daya yang langka atau perselisihan soal tujuan, status, nilai, persepsi, atau kepribadian. Sementara itu Daniel Webster mendefinisikan konflik sebagai: (1) Persaingan atau pertentangan antara pihak-pihak yang tidak cocok satu sama lain, (2) Keadaan atau perilaku yang bertentangan. ${ }^{6}$ Berdasarkan definisi ini, Ihsan Ali Fauzi mengartikan konflik keagamaan sebagai, "perseteruan menyangkut nilai, klaim dan identitas yang melibatkan isuisu keagamaan atau isu-isu yang dibingkai dalam slogan atau ungkapan keagamaan". Pertentangan atau perselisihan sendiri bisa mengambil bentuk perselisihan atau pertentangan ide maupun fisik.

Dahrendorf telah melahirkan kritik penting terhadap pendekatan yang pernah dominan dalam sosiologi, yaitu kegagalan dalam menganalisa masalah konflik sosial. Dia menegaskan bahwa proses konflik sosial itu merupakan kunci bagi struktur sosial. Dahrendorf telah berperan sebagai corong teoritis utama yang menganjurkan agar

\footnotetext{
${ }^{5}$ Wood, Walace, Zeffane, Schermerhom, Hunt dan Osbon, Organisational Behaviour; A Global Prespective (Brisbane: Wiley, 1998), 580.

${ }^{6}$ Wahyudi, A. Konflik, Konsep Teori dan Permasalahan 2015, 2-3.

7 Aisyah BM, S. Konflik. Sosial Dalam Hubungan Antar Umat Beragama. Dakwah Tabligh, 15(2) 2014.
}

42 | Khoirul Mudawinun Nisa', - Konflik Sosial Keagamaan Antar Keagamaan di Dusun Kecil dan Terpencil 
perspektif konflik dipergunakan dalam rangka memahami dengan lebih baik fenomena sosial.

Dahrendorf membedakan golongan yang terlibat konflik itu menjadi dua tipe. Kelompok semu (quasi group) merupakan kumpulan dari para pemegang kekuasaan atau jabatan dengan kepentingan yang sama yang terbentuk karena munculnya kelompok kepentingan. Tipe yang kedua adalah kelompok kepentingan (interest group), terbentuk dari kelompok semu yang lebih luas. Kelompok kepentingan ini mempunyai struktur, organisasi, program, tujuan serta anggota yang jelas. ${ }^{8}$ Kelompok kepentingan inilah yang menjadi sumber nyata timbulnya konflik dalam masyarakat.

Pada konflik masyarakat dusun Bener dengan pengurus ta'mir masjid ini, terjadi harapan peran yang disadari (kepentingan tersembunyi telah disadari). Kelompok kepentingan ini telah memiliki struktur organisasi dan tujuan yang jelas. Para masyarakat dusun Bener menyadari kepentingan yang ia perjuangkan yakni mendapatkan tempat yang layak dan representative untuk mengekspresikan harapan-harapan mereka.

\section{Discontents menjadi Akar Konflik}

Konflik merupakan suatu kenyataan hidup, tidak terhindarkan dan sering bersifat kreatif. Konflik terjadi ketika tujuan masyarakat tidak sejalan. Berbagai perbedaan pendapat dan konflik biasanya diselesaikan tanpa kekerasan dan sering menghasilkan situasi yang lebih baik bagi sebagain besar atau semua pihak yang terlibat. Penyebab konflik menurut Dahrendorf adalah kepemilikan wewenang (otoritas) dalam kelompok yang beragam. Jadi, konflik bukan hanya materi (ekonomi saja).

Dahrendorf menjelaskan penyebab konflik dalam 6 teori utama. Teori hubungan masyarakat menganggap bahwa konflik disebabkan oleh polarisasi yang terus terjadi, ketidakpercayaan dan permusuhan diantara kelompok yang berbeda dalam suatu masyarakat. Teori negosiasi prinsip menganggap bahwa konflik disebabkan oleh posisi yang tidak selaras dan perbedaan pandangan tentang konflik oleh pihak yang mengalami konflik. Teori kebutuhan manusia berasumsi bahwa konflik yang berakar dalam disebabkan oleh kebutuhan dasar manusia baik fisik, mental maupun sosial yang tidak terpenuhi atau dihalangi. Keamanan, identitas, pengakuan, partisipasi dan otonomi sering merupakan inti pembicaraan dalam konflik.

Sementara itu, teori identitas berasumsi bahwa konflik disebabkan karena identitas yang terancam, yang sering berakar pada hilangnya sesuatu atau penderitaan masa lalu yang tidak diselesaikan. Teori kesalahpahaman antarbudaya berpandangan berbeda, teori ini berasumsi bahwa konflik disebabkan oleh ketidakcocokan dakan cara-cara komunikasi diantara berbagai budaya yang berbeda. Teori transformasi konflik berasumsi bahwa konflik disebabkan oleh masalah-masalah ketidakadilan dan ketidaksetaraan yang muncul sebagai masalah sosial, budaya dan ekonomi.

Dinamika konflik menurut Dahrendorf akan muncul karena adanya suatu isu tertentu yang memunculkan dua kelompok untuk berkonflik. Dasar pembentukan kelompok adalah otoritas yang dimiliki oleh setiap kelompok yaitu kelompok yang berkuasa dan kelompok yang dikuasai. Kepentingan kelompok yang berkuasa adalah mempertahankan kekuasaanya sedangkan kelompok yang dikuasai adalah menentang legitimasi otoritas yang ada.

Dahrendorf memandang wewenang dalam masyarakat modern dan industrial sebagai kekuasaan. Relasi wewenang yaitu selalu relasi antara super dan subordinasi.

\footnotetext{
${ }^{8}$ Dahrendorf "Class and Class Conflict in Industrial Society."
} 
Dimana ada relasi wewenang, kelompok-kelompok superordinasi selalu diharapkan mengontrol perilaku kelompok subordinasi melalui permintaan dan perintah serta peringatan dan larangan. Berbagai harapan tertanam relative permanent dalam posisi sosial pada karakter individual. Saat kekuasaan merupakan tekanan satu sama lain, maka kekuasaan dalam hubungan kelompok terkoordinasi ini memeliharanya menjadi legitimasi.

Konflik sosial keagamaan di dusun Bener yang terjadi bersumber pada perbedaan pendapat mengenai program-program baru yang dirilis oleh pengurus ta'mir masjid imam muslim. Perbedaan ideologi menjadi latar belakang munculnya konflik sosial. Berbagai permasalahan dapat disimpulkan sebagai berikut. Pertama, ketidak puasan masyarakat dengan perombakan struktur organisasi ta'mir masjid Imam Muslim oleh pak yai Abu Amar karena didominasi oleh Bani Yahya. Perbedaan tersebut telah melahirkan konflik yang nyata antara pemimpin sebagai pemegang kekuasaan yang melihat keluarga dari Bani Yahya mayoritas berpotensi untuk dimasukkan dalam kepengurusan ta'mir masjid Imam Muslim dengan masyarakat sebagai pihak yang dikuasai menganggap adanya politisasi dari perombakan pengurus ta'mir masjid yang didominasi oleh Bani Yahya sehingga masyarakat yang bukan dari Bani Yahya merasa tidak diberdayakan.

Isu kedua, Produk program baru yang dikeluarkan pengurus ta'mir masjid dianggap tidak relevan dengan kondisi masyarakat, diantara program-program keagamaan tersebut adalah : (a) diadakannya "donatur tetap", masyarakat menganggap program tersebut sebagai "shodaqoh pemaksaan"; (b) pengganjian guru TPQ. Dari hasil shodaqoh para donatur dialokasikan untuk menggaji guru TPQ yang mayoritas pengajarnya dari Bani Yahya. Masyarakat mengganggap adanya motif pengambilan keuntungan untuk menambah finansial keluarga mereka karena masa kepemimpinan mbah yai Imam Mawardi guru TPQ tidak pernah dibayar; (c) program penggiliran penceramah dalam kegiatan rutinan ibu-ibu yang mana kelima orang terpilih berasal dari Bani Yahya. Dari beberapa program yang dianggap tidak sejalan, warga sebagai yang dikuasai berusaha untuk melawan pemegang kekuasaan. Konflik pun muncul ketika pemegang kekuasaan bertahan dalam menggunakan kekuasaannya. Warga dusun Bener semakin melawan dengan pembangkangan tidak mau mengikuti semua kegiatan yang diprogramkan oleh ta'mir masjid dan segala kegiatan yang berpusat di masjid Imam Muslim. Konflik semakin parah dengan munculnya beberapa kubu yang ingin mendirikan musholla baru dan sesbagian kubu memanfaatkan musholla yang sudah ada sebagai pusat kegiatan keagamaan mereka.

Tingkah laku agresif masyarakat Dusun Bener yang terekspresikan dalam konflik social, menurut Ted Robert Gurr ${ }^{9}$ (1970) adalah timbulnya sikap ketidakpuasan atau discontents dimasyarakat luas sebagai akibat luas adanya jarak yang lebar antara value expectation dan values capabilities, sehingga masyarakat sungguh-sungguh merasakan adanya sesuatu yang hilang yang disebut relative deprivation. Lalu muncullah problem social yang menurut Jalaluddin Rakhmat (1999), problem social adalah perbedaan antara das sollen (yang seharusnya kita inginkan terjadi) dan das sein (yang nyata yang terjadi).

\section{Gambar 2:}

9 Ted Robert Gurr, Why Men Rebel, 1970

44 | Khoirul Mudawinun Nisa', - Konflik Sosial Keagamaan Antar Keagamaan di Dusun Kecil dan Terpencil 


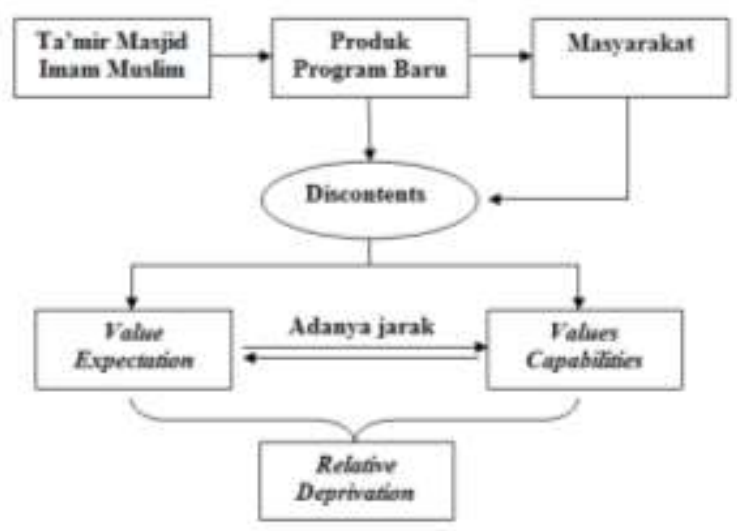

Al-Qur'an juga banyak menyinggung tentang potensi-potensi ketidakbaikan dalam diri manusia. Sebutlah misalnya Q.S. Yusuf /12: 5. ${ }^{10}$ Ayat ini menginformasikan bahwa di dalam diri manusia terdapat kekuatan-kekuatan yang selalu berusaha menarik dirinya untuk menyimpang dari nilai-nilai dan norma ilahi. Potensi destruktif dalam diri bisa mendominasi kalau tidak dinetralisir oleh pengembangan potensi kebaikan dan lingkungan. Dengan kata lain, konflik secara laten ada dalam diri manusia. Potensi konflik ini bisa teraktualisasi kalau keliru memahami ajaran agama. Dan bisa juga dipercepat oleh lingkungan baik ekonomi, sosial, budaya dan lain-lain.

Mencermati hal ini, konflik sosial dalam masyarakat menjadi keniscayaan yang bisa disebabkan karena beberapa faktor seperti: Pertama, perbedaan pendirian atau perasaan individu. Sebagai contoh kecil, program penceramah rutinan yasinan ibu-ibu yang digilir sebanyak, tentu mempunyai perasaan yang tidak sama dalam kaitannya dengan program baru tersebut yang sebelumnya tidak ada. Ada yang suka karena adanya inovasi tidak monoton, ada yang apatis, tetapi tidak terbiasa dengan program baru tersebut sehingga memunculkan argumen-argumen negatif. Perbedaan perasaan ini bisa menyulut konflik kalau tidak dinegosiasikan dengan baik.

Kedua, Perbedaan latar belakang pola asuh keluarga yang membentuk pribadipribadi yang berbeda. Perbedaan pola asuh keluarga juga berpotensi menimbulkan konflik. Sebagai contoh misalnya bisa dilihat ada yang didikan keluarganya demokratis sehingga selalu menghargai perbedaan pendapat, ada yang didikan keluarganya lemah lembut sehingga kurang tegas dalam menyikapi segala hal, bahkan ada yang dibesarkan dengan pola asuh agresif sehingga dalam menghadapi segala perbedaan dengan emosi. Perbedaan pola asuh tersebut jika dalam berinteraksi ada miss communikasi maka akan berpotensi timbulnya konflik. Ketiga, Perbedaan kepentingan antara individu atau kelompok, baik menyangkut politik, ekonomi, sosial, budaya atau agama, juga berpotensi konflik. Keempat, perubahan-perubahan nilai yang cepat dan mendadak dalam masyarakat. ${ }^{11}$

\section{Masyarakat Desa dalam Tinjauan Sosial Budaya}

Pengertian desa menurut kamus Poerwadarminta ${ }^{12}$ (1976) adalah"sekelompok rumah di luar kota yang merupakan kesatuan, kampung (di luar kota); dusun atau udik (dalam arti daerah pedalaman sebagai lawan dari kota)". Desa menurut kamus tersebut terutama dalam arti fisik. Lain lagi dengan istilah desa dalam rembug desa, yang berarti fisik, masyarakat dan pemerintahannya. Istilah lain yang memiliki pengertian hampir sama adalah village.

\footnotetext{
${ }^{10}$ Yayasan Penyelenggara Penterjemah/Penafsir, Al Quran dan Terjemahannya Departemen Agama, 1986.

11 (Aisyah BM, 2014, pp. 192-196)

12 Poerwadarminta, Kamus Umum Bahasa Indonesia (Jakarta: Balai Pustaka, 1976).
} 
Menurut The Random House Dictionary (1968), village adalah: "a small community or group of house in a rural area usually smaller than a town and sometimes incorporated as a municipality".

Definisi tersebut mengandung makna bahwa yang dimaksud dengan masyarakat kecil adalah masyarakat di daerah masyarakat pedesaan. Masyarakat kecil disebut juga rural community yang diartikan sebagai masyarakat yang anggota-anggotanya hidup bersama di suatu lokalitas tertentu, yang seorang merasa dirinya bagian dari kelompok, kehidupan mereka meliputi urusan-urusan yang merupakan tanggungjawab bersama dan masingmasing merasa terikat pada norma-norma tertentu yang mereka taati bersama.

Masyarakat desa selalu memiliki ciri-ciri atau dalam hidup bermasyarakat, yang biasanya tampak dalam perilaku keseharian mereka. Pada situasi dan kondisi tertentu, sebagian karakteristik dapat digeneralisasikan pada kehidupan masyarakat desa di Jawa. Namun demikian, dengan adanya perubahan sosial religius dan perkembangan era informasi dan teknologi, terkadang sebagian karakteristik tersebut sudah "tidak berlaku". Berikut ini disampaikan sejumlah karakteristik masyarakat desa, yang terkait dengan etika dan budaya mereka, yang bersifat umum yang selama ini masih sering ditemui. Setidaknya, ini menjadi salah satu wacana bagi kita yang akan bersama-sama hidup di lingkungan pedesaan, yaitu sederhana, mudah curiga, menjunjung tinggi unggah-ungguh, gotong royong, tepo seliro, guyub rukun, lugas "berbicara apa adanya", tertutup dalam hal keuangan, perasaan "minder" terhadap orang kota, menghargai "ngajeni” orang lain, jika diberi janji akan selalu diingat, suka gotong-royong, demokratis, religious dan lain sebagainya. ${ }^{13}$

Karakteristik masyarakat dusun Bener awal sebelum adanya konflik tidak jauh beda seperti apa yang dijelaskan Waluya diantaranya gotong royong, tepo seliro, guyub rukun dan lain sebagainya. Namun, pasca terjadinya konflik masyarakat dusun Bener mengalami perubahan sikap, seperti: sentimen dan suka berprasangka terhadap kubu lain, mengunggulunggulkan kelompoknya, rasa persaudaraan hilang dan lain sebagainya.

Tabel 1:

Matriks analisa Perubahan Sosial Masyarakat Dusun Bener Pasca Konflik

\begin{tabular}{llll}
\hline No. & $\begin{array}{l}\text { Meluhurnya Nila-nilai Budaya dan } \\
\text { Tradisi }\end{array}$ & Keadaan Awal & Keadaan saat ini \\
\hline 1. & Hilangnya kearifan lokal & - Guyub rukun & - Mengunggulkan \\
& & - Tepo sliro & kelompoknya \\
& & - Individualis \\
\hline 2. & Pudarnya etika & - Menjunjung & - Mudah \\
& tinggi unggah- & berprasangka \\
& ungguh & - Mudah \\
& - Menghargai & tersinggung \\
& "ngajeni" orang & - Berbicara lugas \\
& lain & "apa adanya" \\
\hline
\end{tabular}

Masyarakat ideal yang dicita-citakan Islam adalah masyarakat yang anggotanya saling mencintai (tababub), saling menasehati (tasawi dan tanabi), memiliki rasa persaudaraan (ta'akbiy), bekerja sama (ta'awun), saling mengajar (ta'alum), percampuran (tazawuj), saling menghibur (tawasi) dan saling menemani (tashaduq dan ta'anus). ${ }^{14}$ Masyarakat yang terbangun juga mesti mendahulukan kemaslahatan dan tidak berbuat kerusakan

\footnotetext{
13 (Waluya, 2001, pp. 1-3)

14 Muhammad Obie. 2016. Perubahan Sosial pada Komunitas Suku Bajo di Pesisir Teluk Tomini. Al-Tahrir: Jurnal Pemikiran Islam. Vol. 16 No. 1 Mei 2016. ISSN 1412-7512. 170-171
}

46 | Khoirul Mudawinun Nisa', - Konflik Sosial Keagamaan Antar Keagamaan di Dusun Kecil dan Terpencil 
sebagaimana dijelaskan dalam QS. Al-A'raf: 56. Ayat tersebut menegaskan bahwa penduduk suatu negeri harus beriman dan bertaqwa secara bersama-sama. Hal ini mengisyaratkan bahwa sesama anggota masyarakat harus terintegrasi dan bauh-membahu menuju kondisi masyarakat ideal yang dicita-citakan. Tanggungjawab mewujudkan masyarakat ideal bukanlah tanggungjawab perseorangan tetapi merupakan tanggungjawab kolektif.

Konflik dapat berdampak positif dan negative. Menurut Wijono, bila upaya penanganan dan pengelolaan konflik karyawan dilakukan secara efisien dan efektif maka dampak positif akan muncul melalui perilaku yang dinampakkan oleh sebagai sumber daya manusia potensial dengan berbagai akibat. Sedangkan Dampak negative konflik disebabkan oleh kurang efektif dalam pengelolaannya yaitu ada kecenderungan untuk membiarkan konflik tumbuh subur dan menghindari terjadinya konflik. Akibat munculnya keadaankeadaan. Konflik dapat berakibat negative maupun positif tergantung pada cara mengelola konflik tersebut. Akibat negative berupa : Menghambat komunikasi, Mengganggu kerjasama atau team work, Mengganggu proses produksi, bahkan dapat menurunkan produki, Menumbuhkan ketidakpuasan terhadap pekerjaan, Individu atau peronil mengalami tekanan (stress), mengganggu konsentrasi, menimbulkan kecemasan, mangkir, menarik diri, frustasi, dan apatisme. ${ }^{15}$

Akibat positif konflik meliputi: Membuat organisasi tetap hidup dan harmonis, Berusaha menyesuaikan diri dengan lingkungan, Melakukan adaptasi, sehingga dapat terjadi perubahan dan perbaikan dalam sistem dan prosedur, mekanissme, program, bahkan tujuan organisasi, Memunculkan keputusankeputusan yang bersifat inovatif, Memunculkan persepsi yang lebih kritis terhadap perbedaan pendapat.

Dampak konflik sosial keagamaan antar muslim di dusun Bener dapat digambarkan sebagai berikut:

Tabel 2: Dampak Konflik Dusun Bener

\begin{tabular}{|c|c|c|}
\hline No. & Dampak Positif & Dampak Negatif \\
\hline 1. & $\begin{array}{l}\text { Pemanfaatan tempat ibadah secara } \\
\text { intensif dalam keseharian: } \\
\text { - masyarakat aktif dalam } \\
\text { berjamaah, } \\
\text { - bersemangat dalam bersedekah } \\
\text { - memperindah masing-masing } \\
\text { mushollanya } \\
\text { - memperlihatkan keistiqomahan } \\
\text { dalam berjamaah }\end{array}$ & $\begin{array}{l}\text { - Keaktifan ibadah menjadi persaingan } \\
\text { kelompok } \\
\text { - } \text { saling menonjolkan kemampuan } \\
\text { kelompok pada kegiatan di musholla } \\
\text { masing-masing sehingga } \\
\text { menimbulkan rasa "takabbur". } \\
\text { - } \text { kesempatan untuk bersilaturrahim } \\
\text { pada hari raya Idhul Fitri terabaikan. }\end{array}$ \\
\hline 2. & $\begin{array}{l}\text { - Meningkatnya hubungan } \\
\text { kerjasama yang produktif dalam } \\
\text { kelompoknya masing-masing. } \\
\text { - Meningkatnya motivasi kerja } \\
\text { untuk melakukan kompetisi } \\
\text { dengan kelompok lain }\end{array}$ & 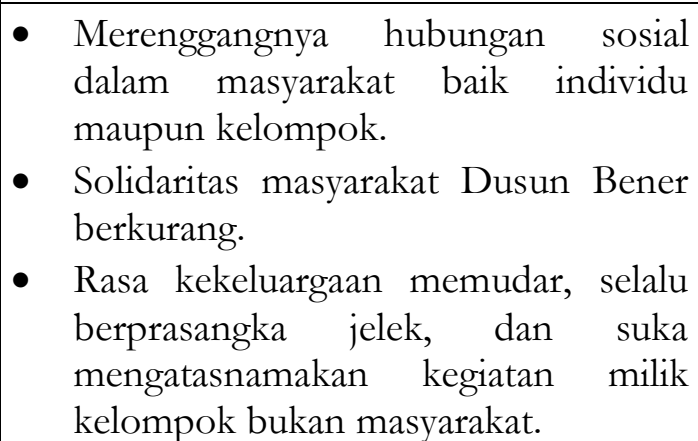 \\
\hline
\end{tabular}

${ }^{15}$ (Wahyudi, 2015, p. 13) 


\section{Kesimpulan}

Konflik yang terjadi antara pengurus ta'mir masjid imam muslim dengan masyarakat jika merujuk pada teori otoritas Dahrendorf, maka dapat disimpulkan bahwa pengurus ta'mir masjid imam muslim merupakan pihak pemegang otoritas sementara masyarakat tidak memegang otoritas. Dalam hal ini, masyarakat berada pada posisi ketidakbebasan yang dipaksakan. Sementara itu, pengurus ta'mir masjid didelegasikan kekuasaan dan otoritas. Maka dari itu, pengurus ta'mir masjid memiliki kewenangan untuk membuat program baru. Berdasarkan kasus konflik sosial keagamaan di dusun Bener, peneliti melihat pemicu atau kar terjadinya konflik adalah adanya perbedaan ideologi antar pemegang kekuasaan (pengurus ta'mir masjid) dengan masyarakat.

Konflik di Dusun Bener berupa konflik pribadi, kepentingan politik, dan ekspresi dalam ibadah atau peribadatan yang mana konflik tersebut dipengaruhi oleh pihak-pihak yang terlibat memicu konflik antara lain tokoh agama, anggota masyarakat dan pemuda. Adapun konflik yang terjadi di dusun Bener berdampak positif dan negatif bagi tempat peribadatan dan bagi antar individu maupun antar kelompok.

\section{Daftar Pustaka}

Abid, N. (2011). Developing A Web-Based Model Using Moodle 1.9 For Teaching And Learning English At Smk. Negeri 1 Jombang. Universitas Islam Malang.

Aisyah BM, S. (2014). Konflik Sosial Dalam Hubungan Antar Umat Beragama. Dakwah Tabligh, 15(2), 189-208.

Dahrendorf, Ralf. 1995. "Class and Calss Conflict in Industrial Society". In David B. Grusky (ed.), Social Statification: Class, Race, and Gender in Sociological Perspective. Boulder-San Francisco-Oxford: Westview Press.

Farihah, I., \& Nurani, I. (2017). Internalisasi Nilai-Nilai Keislaman Dalam Skema Hidden Curriculum Di Mts Nurul Huda Medini Demak. Edukasia: Jurnal Penelitian Pendidikan Islam, 12(1), 213-234. https://doi.org/10.21043/EDUKASIA.V12I1.2347

Indrajit, R. E. (2016). E- Learning dan Sistem Informasi Pendidikan: Modul Pembelajaran Berbasis Standar Kompetensi dan Kualifikasi Kerja (2nd ed.). Yogyakarta: Preinexus.

Obie, Muhammad. 2016. Perubahan Sosial pada Komunitas Suku Bajo di Pesisir Teluk Tomini. Al-Tahrir: Jurnal Pemikiran Islam. Vol. 16 No. 1 Mei 2016.

Poerwadarminta, Kamus Umum Babasa Indonesia Jakarta: Balai Pustaka, 1976.

Ritzer, George. Sosiologi Ilmu Berparadigma Ganda. (Jakarta: Rajawali Press. 2003.

Wahyudi, A. (2015). Konflik, Konsep Teori dan Permasalahan, 1-15.

Waluya, B. (2001). Masyarakat Pedesaan ( Rural Community ). Direktori FPIPS Jurusan Geofrafi. Retrieved from http://file.upi.edu/Direktori/FPIPS/JUR._PEND._GEOGRAFI/197210242001121 -BAGJA_WALUYA/GEOGRAFI_DESAKOTA/Rural_Comunity.pdf

Wood, Walace, Zeffane, Schermerhom, Hunt dan Osbon, Organisational Behaviour; A Global Prespective Brisbane: Wiley, 1998.

Suhanah. (2012). Potensi Kerukunan Konflik Umat Beragama di Kota Madiun Jawa Timur. Harmoni : Jurnal Multikultural dan Multireligius. Vol. XI Januari - Maret 2012.

Yayasan Penyelenggara Penterjemah/Penafsir, Al Quran dan Terjemahannya Departemen Agama, 1986 